4

\title{
GENOTYPIC VARIATION IN BELOW-TO ABOVEGROUND SYSTEMIC INDUCTION OF GLUCOSINOLATES MEDIATES PLANT FITNESS CONSEQUENCES UNDER HERBIVORE ATTACK
}

\author{
MOE BAKHTIARI ${ }^{1 *} \&$ SERGIO RASMANN ${ }^{1}$ \\ ${ }^{1}$ Institute of Biology, University of Neuchâtel, Rue Emile-Argand 11, 2000, Neuchâtel, Switzerland \\ *Corresponding author \\ Authors' information:
}

Moe Bakhtiari: Mojtaba.bakhtiari@unine.ch, ORCID: 0000-0002-2363-7878

Sergio Rasmann: Sergio.rasmann@unine.ch, ORCID: 0000-0002-3120-6226

Running title: Fitness impact of induced systemic resistance

\section{Acknowledgements}

We thank Mégane Rohrer and Ludovico Formenti for assisting with experimental work and trait measurements. This work was supported by Swiss National Science Foundation grants 179481 and 159869 to SR. 
Abstract- Plants defend themselves against herbivore attack by constitutively producing toxic secondary metabolites, as well as by inducing them during herbivore feeding. Induction of secondary metabolites can cross plant tissue boundaries, such as from root to shoot. However, whether the potential for plants to systemically induce secondary metabolites from roots to shoots shows genetic variability, and thus, potentially, is under selection conferring fitness benefits to the plants is an open question. To address this question, we induced 26 maternal plant families of the wild species Cardamine hirsuta belowground (BG) using the wound-mimicking phytohormone jasmonic acid (JA). We measured resistance against a generalist (Spodoptera littoralis) and a specialist (Pieris brassicae) herbivore species, as well as the production of glucosinolates (GSLs) in plants. We showed that BG induction increased AG resistance against the generalist but not against the specialist, and found substantial plant family-level variation for resistance and GSL induction. We further found that the systemic induction of several GSLs tempered the negative effects of herbivory on total seed set production. Using a widespread natural system, we thus confirm that BG to AG induction has a strong genetic component, and it can be under positive selection by increasing plant fitness. We suggest that natural variation in systemic induction is in part dictated by allocation trade-offs between constitutive and inducible GSL production, as well as natural variation in AG and BG herbivore attack in nature.

Key Words - Brassicaceae, Fitness impact of herbivory, Generalist herbivore, Glucosinolates, Induced systemic resistance, Plant-herbivore interaction. 
The selective pressure of insect herbivores on plants has led to the evolution of a wide variety of secondary metabolites that can intoxicate or inhibit digestion capacities of the herbivores during feeding (Futuyma and Agrawal 2009; Schoonhoven et al. 2005). While secondary metabolites can be constitutively stored in plant tissues prior to herbivore attack, herbivore feeding on one organ of a plant can induce the de novo production, or increase accumulation of the toxins locally, on the same organ, or systemically, on other organs of a plant (Kessler and Baldwin 2002). Within-plant induction of toxic chemicals often reduces the performance of current or subsequent herbivores (Karban and Baldwin 1997; Poelman et al. 2008), and therefore, locally- or systemically-induced chemical defenses should be linked to plant fitness (Agrawal 1998; Agrawal 2000). Moreover, the induction of defenses can cross widely-separated plant organs, such as travelling from roots to shoots (Bezemer et al. 2003). Indeed, a growing body of literature is showing that a range of belowground (BG) organisms can induce defense responses in aboveground (AG) tissues and vice versa (Bezemer et al. 2003; Erb et al. 2009; Rasmann and Agrawal 2008; Soler et al. 2005; Staley et al. 2007; van Dam et al. 2005). Reviews on the topic suggest that the magnitude and direction of chemically-mediated AG-BG interactions in plants largely depend on plant genotypic variation as well as the attacking species' identity (Kabouw et al. 2011; van Geem et al. 2013; Vandegehuchte et al. 2011). Therefore, potentially, selection is acting on plants' natural genetic variation to optimize their ability to induce defenses systemically. While significant levels of genetic variation, as well as a heritable genetic basis for both constitutive and inducible defense traits expression has been shown in several systems (Agrawal et al. 2002; Havill and Raffa 1999; Humphrey et al. 2018; Stevens and Lindroth 2005; Underwood et al. 2000; Wagner and Mitchell-Olds 2018), to date, we have practically no information on whether BG-AG defense induction is under positive selection for plants harboring such trait variation in nature. . Measuring BG to AG root induction is also ecologically-relevant since in nature, plants can be potentially in contact with a wide range of root herbivores, that phenologically, can induce the plants before the leaf herbivores arrive (Erb et al. 2008; Huang et al. 2017; Rasmann and Agrawal 2008). 
For a trait to be under selection, it needs to display a significant degree of genetically based variation in nature. Whereas most of such variation is generated by random mutation, and evolutionary and genetic mechanisms (Caliskan 2012), the maintenance of genetic variability can also be affected by energetic costs. Optimal defense theory suggests that inducible defenses have evolved as a cost-saving strategy, and the relative allocation of constitutive and inducible defenses in plant organs, individuals or populations depends on predictability of attack from herbivores, the susceptibility of plants to attacks, and the context dependency of the interaction (e.g. environmental variation) (Agrawal et al. 2002; McKey 1974; Zangerl and Bazzaz 1992; Zangerl and Rutledge 1996). In other words, the simultaneous expression of constitutive and induced defense is thought to be costly (Brody and Karban 1992; Rasmann and Agrawal 2009; Strauss et al. 2002; Zangerl and Bazzaz 1992) and should result in negative genetic correlations (trade-offs) between individual traits and between defense deployment strategies (Agrawal et al. 2010). Therefore, high constitutive expression of a defense trait is predicted to be associated with lower induction abilities. While trade-offs between constitutive and induced defenses on the same organs have been shown in several systems (Heil et al. 2004; Rasmann et al. 2015; Rasmann et al. 2011; Thaler et al. 1999; Thaler and Karban 1997), we still lack evidence for whether AG inducibility of defenses after BG induction is trading-off with constitutive defenses.

In brassicaceaous plants, glucosinolates (GSLs), Sulphur- and nitrogen-containing plant secondary metabolites, are the main defensive compounds conferring plant resistance against insect herbivores (Howe and Jander 2008). The defensive function of GSLs breakdown products, when either expressed constitutively or when induced, against both specialist and generalist insect herbivores has been amply documented (Agrawal 1998; Agrawal 2000; Agrawal et al. 2002; Baldwin 1998; Karban and Baldwin 1997; van Dam and Oomen 2008; van Dam and Raaijmakers 2005; van Dam et al. 2005). Several individual GSLs show strong inducibility following herbivory and generally, the plant hormone jasmonic acid (JA) is a key player in the regulation of induced plant responses against chewing herbivores such as caterpillars (Farmer et al. 2003; Howe and Jander 2008). Emerging patterns from studies on Brassica spp. indicate that BG insect herbivory, or JA application to roots increase total GSLs levels in shoots (Griffiths et al. 1994; Pierre et al. 2012; Soler et al. 2005; van Dam et al. 2004). 
For instance, previous work with Cardamine hirsuta demonstrated that the overall abundance and fitness, particularly, when plants are under herbivore attack.

We here sought for natural genetic variability in BG-to-AG systemic induction in nature and specifically asked the following questions: 1) Does the exogenous application of JA in roots increase resistance against specialist and generalist insect leaf-chewing herbivores? 2) Is there geneticallybased variation in resistance against insects and BG-to-AG induction of GSLs? 3) Is there a trade-off between the constitutive and inducible production of shoot GSLs following root induction? and 4) What is the impact of systemic induction of different GSLs on plant fitness? We answered these questions by inducing the roots of 26 maternal half-sib families of Cardamine hirsuta (Brassicaceae), measured GSL production in the leaves, and measured the growth of a specialist herbivore, the large cabbage butterfly Pieris brassicae, and a generalist noctuid butterfly, Spodoptera littoralis, to assess the potential impact of GSLs on adapted and non-adapted herbivores, respectively Our work builds toward a better understating of the ecological and evolutionary drivers of plant chemical defense variation in nature.

\section{METHODS AND MATERIALS}

Plants and Insects - The hairy bittercress, Cardamine hirsuta (Brassicaceae) is a common weed growing in a variety of habitats in Europe but mainly at low elevations (Pellissier et al. 2016). Seeds from 26 half-sib families were collected from three different natural populations separated by at least $10 \mathrm{Km}$ (pop $\mathrm{A}=9$ pop $\mathrm{B}=10$, and pop $\mathrm{C}=7$ families) at the foothills of the Swiss Jura mountains. After an overwintering period of four months at $4{ }^{\circ} \mathrm{C}$, seeds were germinated in Petri dishes lined with humid filter paper, and one week after germination, 15 seedlings per family (total of 390 plants) were transplanted independently into plastic potting pots $(13 \mathrm{~cm}$ width $\times 10 \mathrm{~cm}$ height $)$ filled with $500 \mathrm{ml}$ of sieved soil ( $1 \mathrm{~cm}$ mesh size) mixed with sand in a 3:1 ratio. The soil/sand mixture was sterilized by autoclave at $120{ }^{\circ} \mathrm{C}$ for four hrs. Plants were immediately transferred to climate-controlled chamber 
and kept at $16 \mathrm{~h} / 22^{\circ} \mathrm{C}-8 \mathrm{~h} / 16^{\circ} \mathrm{C}$ day-night, and $50 \%$ relative humidity conditions. Plants were measure genetic variation across different maternal lines, we would like to acknowledge that the potentially observed genetic differences among families cannot be fully isolated from maternal environmental effects, but because $C$. hirsuta practically completely relies on autogamous selfing for reproduction (Hay et al. 2014), such maternal effects should be minimized in this system. We used the Spodoptera littoralis (Lepidoptera: Noctuidae) as specialist and generalist herbivore insects, respectively. P. brassicae is a specialist herbivore that feeds exclusively on plants producing GSLs, especially on species of the Brassicaceae (Chew 1988). The caterpillars used in this experiment were obtained from a culture maintained on Brassica rapae ssp. chinensis (L) plants. S. littoralis is a generalist herbivore known to feed on species belonging to more than forty families of plants (Brown and Dewhurst 1975). However, it does not occur in Switzerland, therefore, it functioned as a generalist, non-adapted, herbivore in our study. Eggs were obtained from Syngenta, Stein AG, Switzerland, and newly hatched S. littoralis larvae to be used in the bioassays were reared on cornbased artificial diet until the beginning of the experiment.

Experimental Design and Insect Bioassay - After three weeks of growth, we randomly assigned the plants to three treatment groups. Six plants per family were randomly assigned to the JA treatment, another six group plants to the no-induction treatment, and the rest (three plants per family) to the noherbivory control treatment. Each plant in the JA treatment were inoculated with $20 \mathrm{ml}$ of JA solution in the roots by spiking the solution into the soil, $0.5 \mathrm{~cm}$ below the surface. The JA solution consisted of $2.4 \mu$ moles $(500 \mu \mathrm{g})$ of JA ( \pm - jasmonic acid, Sigma, St Louis, IL, USA) per plant in $10 \mathrm{ml}$ demineralized water and 0.5\% EtOH (van Dam and Oomen 2008; van Dam et al. 2004). The no158 induction group of plants received $20 \mathrm{ml}$ of $0.5 \% \mathrm{EtOH}$ in acid water ( $\mathrm{pH} 3.7$ with $\mathrm{HCl}$ ). We chose to 159 induce roots with JA instead of using a root herbivore (e.g. cabbage root maggots), in order to standardize the induction event across all plant families. Moreover, by applying JA, we intentionally 
avoided the effect of tissue removal per se on plant fitness. In other words, we were able to measure the fitness impact of defense induction independently from herbivore damage.

To measure the effect of BG induction on leaf chemistry, four days after JA root application, we collected two fully-expanded new leaves per plant in the JA and the no-induction treatments, and immediately froze and stored them at $-80^{\circ} \mathrm{C}$ for further chemical analyses. Since the leaves from both treatments were collected prior to AG herbivory, the plant materials collected from no-induction treatment served for measuring constitutive secondary metabolites expression. Immediately after leaf removal, we infested half of the plants in the herbivory treatments (three plants per family per induction treatment $=$ six plants/family) with two 7-days old S. littoralis larvae, and the other half, with one 6-days old P. brassicae larvae. We next covered all plants with gauze bags to prevent escape or cross-movement of insects between plants. After one week of herbivory, bags were removed, the insects were retrieved from individual plants, and their combined weight per plant was measured and recorded to obtain the average insect weight per plant. We used the formula $\ln ($ final weight initial weight) to determine the insects' weight gain and plant resistance (i.e. lower growth rate indicate that plants are more resistant). After the herbivore bioassay, we allowed the plants to complete their life cycle and produce seeds. To estimate the total seed production on each plant, we first randomly selected one seedpod per plant from 50 plants, measured each pod's length, and counted the number of seeds per pod. Using these data, we fitted a linear regression of the seed number as the function of seedpod length in order to obtain the seed set of each plants based on the seedpod length (equation: $14.92 \times$ total pods length +1.65 ). At the end of the experiment, when all seedpods were mature, AG plant parts were separated from roots, oven-dried at $40^{\circ} \mathrm{C}$ for $48 \mathrm{~h}$ and weighted to 182 determine their dry biomass, which served as covariate in the statistical analyses (see below).

Glucosinolate Analyses - We assessed the concentration of individual GSLs in leaf tissues in noinduction and root-JA-induction plants prior to the AG herbivore application. This allowed measuring the chemical content of the leaves to which the herbivores were immediately exposed across different treatments, and to measure the direct effect of the root induction treatment on plant chemistry without the confounding effect of additional herbivore feeding. To this end, we ground the fresh leaves to 
powder using mortars and pestles in liquid nitrogen. A 100-mg aliquot of fresh leaf powder was then added with $1.0 \mathrm{ml}$ Methanol: H2O: formic acid (80:19.5:0.5, v/v) and 5 glass beads in Eppendorf tubes, shaken in a tissuelyser (Mixer Mill MM 400, Retsch GmbH, Haan, Germany) for 4 min at 30 Hertz, and centrifuged them at $12800 \mathrm{~g}$ for $3 \mathrm{~min}$. The supernatant was then transferred to HPLC vials for liquid chromatography analysis. Glucosinolate identification and quantification was performed using an Acquity UPLC from Waters (Milford, MA, USA) interfaced to a Synapt G2 QTOF from Waters with electrospray ionization, using the separation and identification method as described in Glauser et al. (2012).

Statistical Analyses-All statistical analyses were carried out with R software (R Development Core Team 2017).

1) Does the exogenous application of JA in roots increase resistance against specialist and generalist insect leaf-chewing herbivores? To answer this question we performed two ANOVAs on the larval weight gain, for generalist and specialist respectively, with the JA treatment (two levels) as fixed factor.

2) Is there genetically-based variation in insect resistance and BG-to-AG GSLs induction? First, we assessed the effect of JA treatment (two levels) and maternal families (26 families) on the abundance and composition of all GSLs simultaneously using a permutational multivariate analysis of variance (PERMANOVA) with the adonis function in the package vegan (Oksanen et al. 2017). We included plant biomass as covariate to control for potential direct effect of plant size (Züst et al. 2015) on GSL production, and populations as strata in the model. The results were visualized using a non-metric multidimensional scaling (NMDS) ordination. The Bray-Curtis metric was used to calculate a dissimilarity matrix of all compounds among samples for both the PERMANOVA and the NMDS. Second, to address the effect of root JA-addition and family variation on all i) individual GSLs production, ii) the total amount of GSLs, iii) the AG resistance against $P$. brassicae and $S$. littoralis (insect weight gain), iv) and the seed production, we ran linear mixed-effect models with JA treatment 
covariate, using the function lme in the package nlme (Pinheiro et al. 2017). Because families were

included as random factor in the initial model, we estimated their effect by running a second model

without the nested family factor. Differences between the first and the second models (AIC scores) and Chi-Square tests (function Chisquare in R). In addition, to test for family-level genetic variation in inducibility (G x E) on all individual GSLs and total amount of GSLs per plant, we ran ANCOVAs with JA treatment, plant families nested within populations and their interactions as fixed factors, and plant biomass as covariate, using the function $l m$ in $\mathrm{R}$.

3) Is there a trade-off between the constitutive and inducible production of shoot GSLs following root induction? To test for trade-offs between the constitutive production and the inducibility of total GSLs among the 26 plant families, we employed a Monte Carlo simulation procedure proposed by Morris et al. (2006) using MATLAB (Version 7.5.0.342 -R2007b, MathWorks Inc., USA). This statistical approach accounts for several issues that have apparently confounded previous attempts to assess a trade-off between constitutive and induced defenses (Morris et al. 2006). Specifically, this approach uses the difference in mean GSL production between JA-treated and control plants for measuring induced production of GSLs, and uses a modified Monte Carlo procedure that takes into account sampling variation due to limited sample size, measurement error from environmental and genetic differences.

4) What is the impact of systemically inducing different GSLs on plant fitness? First, we tested for the effect of treatment (3 levels in this case: root JA induction, no-induction, no-herbivory control treatment) on lifetime seed production using mixed effect models with JA treatment as fixed factor and families nested in populations as random factor, including biomass as covariate (lme function), followed by pairwise comparisons using Tukey HSD post-hoc tests (lsmeans function in the package

242 lsmeans (Lenth 2016). Second, to estimate the lifetime fitness effect of root JA induction across all 243 different GSLs, we ran mixed effect ANCOVA models with seed production per plant as response 
categorical fixed factors in the model, respectively. Plant families nested within population were included as random factor using the function lme in the package nlme. The aim here was to detect a significant interaction between JA induction and GSLs on seed set (as a proxy for plant fitness). If this were the case, it would indicate that the effect of JA treatment on a particular GSL compound would affect plant fitness, positively or negatively.

\section{Effect of JA Treatment on Insect Resistance - We found that S. littoralis larvae on JA-treated plants} grew $47 \%$ less compared to control plants (Fig. 1, Table 1), and maternal families responded differently in resistance against this generalist herbivore (Fig. 2a, Table 1). In contrast, P. brassicae larval weight gain did not differ between treatments and there was no family effect on larval weight gain (Table 1).

Effect of JA Treatment and Family Level Variations on GSL Production - The GSL profile of the $C$. hirsuta leaves consisted of 28 GSL compounds: 15 aliphatic-GSLs, 8 aromatic-GSLs, 3 indole-GSLs, and 2 unknown GSLs (Supplementary materials Table S1; Fig. 3a). We found that the maternal family background, but not the JA application, affected the multivariate GSL matrix in C. hirsuta leaves (Table 2, Fig. 3b). Specifically, maternal families explained $35 \%$ of the variance in the PERMANOVA, and such variation was also marginally explained by plant biomass (Table 2). We also found a maternal family effect for 16 out of the 28 GSLs (Table 1), a JA effect for five GSLs (GSL9: glucohirsutin, GSL12: 8-methylthiooctyl gsl, GSL14: hydroxymethylbutyl gs1, GSL17: veratryl gsl, GSL26: neoglucobrassicin; Table 1), and a biomass effect for four GSLs (GSL11: glucoberteroin, GSL24: glucobrassicin, GSL25: methoxyglucobrassicin, GSL26: neoglucobrassicin; Table 1). JA treatment significantly decreased the production of four out of those five compounds, except neoglucobrassicin, which increased its production by $25 \%$. The production of GSL neoglucobrassicin was also significantly affected by plant biomass and the maternal families treatment, which explained $11 \%$ of the total variances (Table 1). We found no effect of JA treatment 
and maternal family on total levels of GSLs (Table 1). In addition, we found a significant interactive effect of family $\times$ JA (maternal family effect for induced production) for five GSLs (GSL1: glucoraphanin, GSL9: glucohirsutin, GSL10: glucoerucin, GSL13: gluconapoleiferin, GSL20: 5benzoyloxypentyl) (Table S2).

Effect of herbivory on Seed Set - Across all families, lifetime seed production in the control (noherbivory) treatment was significantly higher compared to plants in induced and no-induction treatment that experienced herbivory (Fig. $4, F_{1,144}=54.70, p<.0001$ ). While P. brassicae and $S$. littoralis herbivory generally decreased seed set by $68 \%$ and $40 \%$, respectively, we found strong genetic effect on seed set production after S. littoralis herbivory (Table 1, Fig. 2b). Finally, we found no significant JA treatment effect on seed set (Table 1, Fig. 4)

Trade-offs Analyses - We detected a significant negative correlation (trade-off), between the constitutive production and the inducibility of total GSLs across all maternal families of $C$. hirsuta $(r$ $=-0.82, p=0.01$, Fig. S1).

Effect of JA Root Induction on Plant Fitness after Herbivore Attack - Mixed effect ANCOVA analyses showed that five GSLs (GSL4: glucoalyssin, GSL8: glucobrassicanapin, GSL10: glucoerucin, GSL11: glucoberteroin, GSL18: glucotropeolin), as well as the total GSLs production interacted with JA treatment for explaining seed production (Fig. 5, Table S3). In other words, JA induction changed the slope of the relationship between the GSLs and seed production from negative to neutral or even positive (Fig. 5). We also found marginally significant effect of JA $\times$ GSL for GSL16: sinalbin and GSL13: gluconapoleiferin.

We found that the systemic induction, from below- to aboveground, of C. hirsuta plants significantly decreased the weight gain of a generalist leaf chewing herbivore, but such effect was highly variable 
across plant maternal families. Analyses of plants' secondary metabolites showed that JA root

induction affected the production of several GSLs aboveground, and significantly ameliorated plant ecology and evolution of plant defense against herbivores in natural brassicaceaous systems.

Effect of Root JA Treatment on Insect Resistance and Aboveground Glucosinolate Production.

305 One of the principal results of our study is that the JA root application increased resistance against the generalist herbivore (S. littoralis), while JA application had no effect on the specialist herbivore $(P$. brassicae). These results are in line with several previous studies (Bodenhausen and Reymond 2007; Giamoustaris and Mithen 1995; Lankau 2007; Raybould and Moyes 2001). For instance, root JA application to Brassica oleracea roots resulted in reduced weight gain of generalist herbivore Mamestra brassicae, whereas the specialist P. rapae was unaffected (van Dam and Oomen 2008), and root induction resulted in more infestation by AG specialists in field-grown B. oleracea plants (Pierre et al. 2013). Indeed, specialist herbivores of the Brassicaceae not only tolerate GSLs, they also utilize these compounds in host recognition (Raybould and Moyes 2001). On the other hand, the negative effect of GSLs on generalist herbivore performance has also been confirmed in previous studies (Rasmann et al. 2015; Schlaeppi et al. 2008; Schweiger et al. 2014; Schweizer et al. 2017), which confirms strong context-dependency in plant-herbivore interaction.

317 Contrary to general expectations, we did not detect differences in the production of total GSLs 318 between control and JA-treated plants, and found that the GSL production in leaves was related by a 319 large extend to plant biomass, a common phenomenon when studying secondary metabolite production in plants (Glynn et al. 2003; Traw 2002; Züst et al. 2015). Although previous works with Brassicaceae plants showed that BG herbivory, or root induction by JA, increases total levels of GSL in shoots (Griffiths et al. 1994; Pierre et al. 2012; van Dam and Oomen 2008; van Dam et al. 2004), 323 similarly to this one, other studies failed to detect such changes in production of total GSLs (Agrawal 324 2000; Pierre et al. 2013). These results indicate that the systemic induced responses in plants from BG 325 to AG can be species (as well as genotypic, such as in this study) specific, and that uniquely measuring the total amount can often be misleading in plant-herbivore interaction studies. . 
Changes in phytochemical diversity in response to induction is, on the other hand, likely a more important component of plant defense against herbivory (Agrawal 2000; Berenbaum and Zangerl 1996; Lindig-Cisneros et al. 1997). Accordingly, the results of our multivariate analysis showed that among the five families that are distinctive with respect to their GSL profiles (Fig. 1b.), two families exhibited greater resistance against $S$. littoralis (family $5 \& 7$ ). In fact, family 7 , which showed the most distinctive GSL composition in the NMDS, was the most responsive family to JA treatment in terms of inducibility of overall GSLs and the most-resistant family against herbivory by S. littoralis. In addition, in contrast to total GSL levels, we observed that an indolic GSL, neoglucobrassicin, is the only compound that was both significantly induced by JA (Table 1) and also negatively correlated with $S$. littoralis weight gain (results not shown, but results from linear mixed model for testing the interactive effect of the JA treatment and neoglucobrassicin production on S. littoralis weight gain: JA effect; $F_{x, y}=18.34, p<0.001 ;$ neoglucobrassicin effect; $F_{x, y}=5.34, p=0.02$; and their interaction: $F_{x, y}$ $=3.46, \mathrm{P}=0.07)$. Indole GSLs have been shown to be induced by herbivory and to affect the growth and development of insect herbivores in other systems (Irwin et al. 2003; Rostás et al. 2002). Selective induction of indolic GSLs have been reported in B. napus, B. rapae and B. juncea in response to herbivory by flea beetles (Bodnaryk 1992). For instance, the concentration of neoglucobrassicin was increased considerably in leaves of B. napus as a result of topical application of methyl JA to aerial part of the plant (Doughty et al. 1995), as well as in B. rapae and B. napus plants treated with specialist herbivores (Koritsas et al. 1991; Rostás et al. 2002). The same pattern of induction of neoglucobrassicin was observed in the roots of B. napus that were damaged by Delia floralis root maggots (Hopkins et al. 1998). In another study, the only compound that was shown to affect the performance of P. rapae feeding on B. oleracea plants was neoglucobrassicin (Harvey et al. 2007)..

349 Together, these results suggest that the total amount of GSLs in Brassicaceaous plants can often be misleading when predicting plant resistance, while, on the other hand, individual GSLs bear differential toxicities might be better predictors of plant resistance. 
Demonstrating the effect of induced response on plant fitness is crucial for documenting that they truly serve as a defensive response (Erb 2018). We found that herbivory, overall, decreased plant fitness (seed production) by more than $50 \%$, clearly confirming the well-documented negative consequence Mothershead and Marquis 2000). If herbivory decreases plant fitness and plants possess genetic variation for traits affecting herbivory and enhancing fitness, then herbivores may act as strong selective agents for more resistant plants by promoting inducibility of specific toxic molecules. Accordingly, in C. hirsuta, we showed that root JA-mediated induced systemic production of seven GSL compounds in shoots increases seed production in plants exposed to shoot herbivory, compared to plants that did not received JA treatment. This fitness impact has important implications. First, inducible systemic resistance may be an example of adaptive plasticity in plants. Adaptive plasticity is defined by the higher fitness of individuals expressing different phenotypes in a particular environment (Vijendravarma et al. 2015). Thus, the induction of GSLs compounds after root damage can be seen as an adaptive plastic response for C. hirsuta plants (Agrawal 1999; Agrawal 2000). Nonetheless, to be fully convincing, arguments about adaptive plastic responses should also be linked to ecological setting. In this case, we could speculate that $C$. hirsuta plants are likely damaged in their roots, by e.g. root fly maggots, every spring before pierids or other generalist butterflies start feeding on these plants. To date, due to obvious methodological limitations of measuring rates of root herbivory in the field, we only have anecdotal information on the timing and amount of root damage in natural systems (Johnson and Rasmann 2015). For now we can only speculate that the observed genetic variation in inducibility from below to aboveground is shaped by the natural variation in root and shoot herbivory.

376 The second implication of our fitness-related results concerns the evolution of the systemic response 377 from root to shoots. In order for such a trait to evolve by natural selection, there must be heritable variation that affects fitness. We detected genetic variation in induced production of five GSL

379 compounds (significant interactive family $\times$ JA effect). Within these five GSLs, two compounds 380 (GSL10 and 13) were among the seven individual compounds found to be positively affecting seed set 
381 when induced by JA. In other words, plant families possessing the ability for increased production of

382 these seven compounds in the induced state could hinder the negative fitness effect of herbivory.

383 Finally, genetic variation in inducibility could also have been maintained by physiological trade-offs.

384 Accordingly, we showed that the inducibility of total GSLs and neoglucobrassicin negatively

385 correlated with constitutive investment in both traits. It is generally assumed that constitutive and

386 induced defenses should trade off, as the anti-herbivore defenses are costly for plants (Karban and

387 Baldwin 1997; Karban and Myers 1989; Zangerl and Bazzaz 1992). Thus, most C. hirsuta families

388 employ economy in direct chemical defense production, by favoring either a constitutive or an

389 inducible strategy. Altogether, ecological and physiological trade-offs may contribute in maintaining

390 the necessary genetic variation in inducibility of specific GSLs, ultimately generating the raw material

391 for selection to act upon.

392

393

394

395

396

397

398

399

400

401

402

403

404

405

406

407

408 
bioRxiv preprint doi: https://doi.org/10.1101/810432; this version posted October 18, 2019. The copyright holder for this preprint (which was not certified by peer review) is the author/funder, who has granted bioRxiv a license to display the preprint in perpetuity. It is made available under aCC-BY-NC-ND 4.0 International license.

\section{Author contributions}

$410 \mathrm{MB}$ and SR conceived and designed the experiments. MB conducted experiments and chemical

411 analyses. MB and SR analysed the data and wrote the manuscript. The authors declare no conflicts of 412 interest.

413 
Agrawal AA (1998) Induced Responses to Herbivory and Increased Plant Performance Science 279:1201-1202 doi:10.1126/science.279.5354.1201

Agrawal AA (1999) Induced responses to herbivory in wild radish: Effects on several herbivores and plant fitness Ecology 80:1713-1723 doi:doi:10.1890/00129658(1999)080[1713:IRTHIW]2.0.CO;2

Agrawal AA (2000) Benefits and costs of induced plant defense for Lepidium virginicum (Brassicaceae) Ecology 81:1804-1813 doi:10.1890/00129658(2000)081[1804:BACOIP]2.0.CO;2

Agrawal AA, Conner JK, Johnson MTJ, Wallsgrove R (2002) Ecological genetics of an induced plant defense against herbivores: Additive genetic variance and costs of phenotypic plasticity Evolution 56:2206-2213 doi:doi:10.1111/j.0014-3820.2002.tb00145.x

Agrawal AA, Conner JK, Rasmann S (2010) Tradeoffs and negative correlations in evolutionary ecology. In: Evolution since Darwin; the first 150 years, vol 150. 1 edn. Sinauer Associates, Stony Brook, NY, pp 243-268

Bakhtiari M, Glauser G, Rasmann S (2018) Root JA induction modifies glucosinolate profiles and increases subsequent aboveground resistance to herbivore attack in Cardamine hirsuta Frontiers in Plant Science 9 doi:10.3389/fpls.2018.01230

Baldwin IT (1998) Jasmonate-induced responses are costly but benefit plants under attack in native populations Proceedings of the National Academy of Sciences 95:8113-8118 doi:10.1073/pnas.95.14.8113

Berenbaum MR, Zangerl AR (1996) Phytochemical diversity. In: Romeo JT, Saunders JA, Barbosa P (eds) Phytochemical Diversity and Redundancy in Ecological Interactions. Springer US, Boston, MA, pp 1-24. doi:10.1007/978-1-4899-1754-6_1

Bezemer TM, Wagenaar R, Van Dam NM, Wäckers FL (2003) Interactions between above- and belowground insect herbivores as mediated by the plant defense system Oikos 101:555-562 doi:10.1034/j.1600-0706.2003.12424.x

Bodenhausen N, Reymond P (2007) Signaling pathways controlling induced resistance to insect herbivores in Arabidopsis Molecular Plant-Microbe Interactions 20:1406-1420 doi:10.1094/MPMI-20-11-1406

Bodnaryk RP (1992) Effects of wounding on glucosinolates in the cotyledons of oilseed rape and mustard Phytochemistry 31:2671-2677 doi:10.1016/0031-9422(92)83609-3

Brody AK, Karban R (1992) Lack of a tradeoff between constitutive and induced defenses among varieties of cotton Oikos:301-306

Brown ES, Dewhurst CF (1975) The genus Spodoptera (Lepidoptera, Noctuidae) in Africa and the Near East Bulletin of Entomological Research 65:221-262 doi:10.1017/S0007485300005939

Caliskan M (2012) The molecular basis of plant genetic diversity. IntechOpen. doi:10.5772/2639 Chew FS (1988) Biological effects of glucosinolates. In: Biologically Active Natural Products, vol 380. ACS Symposium Series, vol 380. American Chemical Society, pp 155-181. doi:doi:10.1021/bk1988-0380.ch01210.1021/bk-1988-0380.ch012

Doughty KJ, Kiddle GA, Pye BJ, Wallsgrove RM, Pickett JA (1995) Selective induction of glucosinolates in oilseed rape leaves by methyl jasmonate Phytochemistry 38:347-350

Erb M (2018) Plant defenses against herbivory: Closing the fitness gap Trends in Plant Science 23:187194 doi:10.1016/j.tplants.2017.11.005

Erb M et al. (2009) Signal signature of aboveground-induced resistance upon belowground herbivory in maize The Plant Journal 59:292-302 doi:10.1111/j.1365-313X.2009.03868.x

Erb M, Ton J, Degenhardt J, Turlings TCJ (2008) Interactions between arthropod-induced aboveground and belowground defenses in plants 146:867-874 doi:10.1104/pp.107.112169 \%J Plant Physiology 
Farmer EE, Alméras E, Krishnamurthy V (2003) Jasmonates and related oxylipins in plant responses to pathogenesis and herbivory Current Opinion in Plant Biology 6:372-378 doi:10.1016/s13695266(03)00045-1

Futuyma DJ, Agrawal AA (2009) Macroevolution and the biological diversity of plants and herbivores 106:18054-18061 doi:10.1073/pnas.0904106106 \%J Proceedings of the National Academy of Sciences

Giamoustaris A, Mithen R (1995) The effect of modifying the glucosinolate content of leaves of oilseed rape (Brassica napus ssp. oleifera) on its interaction with specialist and generalist pests Annals of Applied Biology 126:347-363 doi:doi:10.1111/j.1744-7348.1995.tb05371.x

Glauser G, Schweizer F, Turlings TC, Reymond P (2012) Rapid profiling of intact glucosinolates in Arabidopsis leaves by UHPLC-QTOFMS using a charged surface hybrid column Phytochem Anal 23:520-528 doi:10.1002/pca.2350

Glynn C, Herms DA, Egawa M, Hansen R, Mattson WJ (2003) Effects of nutrient availability on biomass allocation as well as constitutive and rapid induced herbivore resistance in poplar Oikos 101:385-397 doi:10.1034/j.1600-0706.2003.12089.x

Griffiths DW, Birch ANE, Macfarlane-Smith WH (1994) Induced changes in the indole glucosinolate content of oilseed and forage rape (Brassica napus) plants in response to either turnip root fly (Delia floralis) larval feeding or artificial root damage Journal of the Science of Food and Agriculture 65:171-178 doi:10.1002/jsfa.2740650208

Harvey JA, Gols R, Wagenaar R, Bezemer TM (2007) Development of an insect herbivore and its pupal parasitoid reflect differences in direct plant defense Journal of Chemical Ecology 33:15561569 doi:10.1007/s10886-007-9323-0

Havill NP, Raffa KF (1999) Effects of elicitation treatment and genotypic variation on induced resistance in Populus: impacts on gypsy moth (Lepidoptera: Lymantriidae) development and feeding behavior Oecologia 120:295-303

Hay AS et al. (2014) Cardamine hirsuta: a versatile genetic system for comparative studies 78:1-15 doi:10.1111/tpj.12447

Heil $\mathrm{M}$ et al. (2004) Evolutionary change from induced to constitutive expression of an indirect plant resistance Nature 430:205 doi:10.1038/nature02703

Hopkins RJ, Griffiths DW, Birch ANE, McKinlay RG (1998) Influence of increasing herbivore pressure on modification of glucosinolate content of swedes (Brassica napus spp. rapifera) Journal of Chemical Ecology 24:2003-2019 doi:10.1023/a:1020729524818

Howe GA, Jander G (2008) Plant immunity to insect herbivores Annu Rev Plant Biol 59:41-66 doi:10.1146/annurev.arplant.59.032607.092825

Huang W, Robert CAM, Hervé MR, Hu L, Bont Z, Erb M (2017) A mechanism for sequence specificity in plant-mediated interactions between herbivores 214:169-179 doi:10.1111/nph.14328

Humphrey PT, Gloss AD, Frazier J, Nelson-Dittrich AC, Faries S, Whiteman NK (2018) Heritable plant phenotypes track light and herbivory levels at fine spatial scales Oecologia 187:427-445 doi:10.1007/s00442-018-4116-4

Irwin RE, Strauss SY, Storz S, Emerson A, Guibert G (2003) The role of herbivores in the maintenance of a flower color polymorphism in wild radish Ecology 84:1733-1743 doi:doi:10.1890/00129658(2003)084[1733:TROHIT]2.0.CO;2

Johnson SN, Rasmann S (2015) Root-feeding insects and their interactions with organisms in the rhizosphere Annual Review of Entomology 60:517-535 doi:10.1146/annurev-ento-010814020608

Kabouw P et al. (2011) Effects of soil organisms on aboveground multitrophic interactions are consistent between plant genotypes mediating the interaction Entomologia Experimentalis et Applicata 139:197-206 doi:doi:10.1111/j.1570-7458.2011.01123.x

Karban R, Baldwin IT (1997) Induced responses to herbivory Chicago : The University of Chicago Press,

Karban R, Myers JH (1989) Induced plant responses to herbivory Annual Review of Ecology and Systematics 20:331-348 doi:10.1146/annurev.es.20.110189.001555 
Kessler A, Baldwin IT (2002) Plant responses to insect herbivory: The emerging molecular analysis Annual Review of Plant Biology 53:299-328 doi:10.1146/annurev.arplant.53.100301.135207

Kessler A, Baldwin IT (2004) Herbivore-induced plant vaccination. Part I. The orchestration of plant defenses in nature and their fitness consequences in the wild tobacco Nicotiana attenuata The Plant Journal 38:639-649 doi:doi:10.1111/j.1365-313X.2004.02076.x

Koritsas V, Lewis J, Fenwick G (1991) Glucosinolate responses of oilseed rape, mustard and kale to mechanical wounding and infestation by cabbage stem flea beetle (Psylliodes chrysocephala) Annals of Applied Biology 118:209-221

Lankau RA (2007) Specialist and generalist herbivores exert opposing selection on a chemical defense New Phytologist 175:176-184 doi:doi:10.1111/j.1469-8137.2007.02090.x

Lenth RV (2016) Least-Squares Means: The $\{$ R\} Package \{lsmeans\} Journal of Statistical Software 69:133 doi:10.18637/jss.v069.i01

Lindig-Cisneros R, Benrey B, Espinosa-García FJ (1997) Phytoalexins, resistance traits, and domestication status in Phaseolus coccineus and Phaseolus lunatus Journal of Chemical Ecology 23:1997-2011 doi:10.1023/B:JOEC.0000006485.38713.8c

Maron JL (1998) Insect herbivory above- and belowground: Individual and joint effects on plant fitness Ecology 79:1281-1293 doi:doi:10.1890/0012-9658(1998)079[1281:IHAABI]2.0.CO;2

McKey D (1974) Adaptive patterns in alkaloid physiology The American Naturalist 108:305-320

Morris WF, Traw MB, Bergelson J (2006) On testing for a tradeoff between constitutive and induced resistance Oikos 112:102-110 doi:doi:10.1111/j.0030-1299.2006.14253.x

Mothershead K, Marquis RJ (2000) Fitness impacts of herbivory through indirect effects on plantpollinator interactions in Oenothera macrocarpa Ecology 81:30-40 doi:doi:10.1890/00129658(2000)081[0030:FIOHTI]2.0.CO;2

Oksanen J et al. (2017) Vegan: community ecology package Journal of Statistical Software

Pellissier L et al. (2016) The simultaneous inducibility of phytochemicals related to plant direct and indirect defences against herbivores is stronger at low elevation Journal of Ecology 104:11161125 doi:10.1111/1365-2745.12580

Pierre PS, Dugravot S, Cortesero AM, Poinsot D, Raaijmakers CE, Hassan HM, van Dam NM (2012) Broccoli and turnip plants display contrasting responses to belowground induction by Delia radicum infestation and phytohormone applications Phytochemistry 73:42-50 doi:10.1016/j.phytochem.2011.09.009

Pierre SP, Dugravot S, Herve MR, Hassan HM, van Dam NM, Cortesero AM (2013) Belowground induction by Delia radicum or phytohormones affect aboveground herbivore communities on field-grown broccoli Front Plant Sci 4:305 doi:10.3389/fpls.2013.00305

Pinheiro J, Bates D, DebRoy S, Sarkar D, R Core Team (2017) \{nlme\}: Linear and Nonlinear Mixed Effects Models Journal of Statistical Software

Poelman EH, van Loon JJA, Dicke M (2008) Consequences of variation in plant defense for biodiversity at higher trophic levels Trends in Plant Science 13:534-541 doi:10.1016/j.tplants.2008.08.003

R Development Core Team (2017) R: A language and environment for statistical computing, 3.4.0 edn. R Foundation for Statistical Computing, Vienna, Austria

Rasmann S, Agrawal AA (2008) In defense of roots: A research agenda for studying plant resistance to belowground herbivory Plant Physiology 146:875-880 doi:10.1104/pp.107.112045

Rasmann S, Agrawal AA (2009) Plant defense against herbivory: progress in identifying synergism, redundancy, and antagonism between resistance traits Current opinion in plant biology $12: 473-478$

Rasmann S, Chassin E, Bilat J, Glauser G, Reymond P (2015) trade-off between constitutive and inducible resistance against herbivores is only partially explained by gene expression and glucosinolate production Journal of Experimental Botany 66:2527-2534 doi:10.1093/jxb/erv033

Rasmann S, Erwin AC, Halitschke R, Agrawal AA (2011) Direct and indirect root defences of milkweed (Asclepias syriaca): trophic cascades, trade-offs and novel methods for studying 
subterranean herbivory Journal of Ecology 99:16-25 doi:doi:10.1111/j.13652745.2010.01713.x

Raybould A, Moyes C (2001) The ecological genetics of aliphatic glucosinolates Heredity 87:383

Rostás M, Bennett R, Hilker M (2002) Comparative physiological responses in Chinese cabbage induced by herbivory and fungal infection Journal of Chemical Ecology 28:2449-2463 doi:10.1023/a:1021427917603

Schlaeppi K, Bodenhausen N, Buchala A, Mauch F, Reymond P (2008) The glutathione-deficient mutant pad2-1 accumulates lower amounts of glucosinolates and is more susceptible to the insect herbivore Spodoptera littoralis The Plant Journal 55:774-786 doi:doi:10.1111/j.1365313X.2008.03545.X

Schoonhoven LM, Van Loon B, van Loon JJ, Dicke M (2005) Insect-plant biology. Oxford University Press on Demand,

Schweiger R, Heise AM, Persicke M, Muller C (2014) Interactions between the jasmonic and salicylic acid pathway modulate the plant metabolome and affect herbivores of different feeding types Plant Cell Environ 37:1574-1585 doi:10.1111/pce.12257

Schweizer F, Heidel-Fischer H, Vogel H, Reymond P (2017) Arabidopsis glucosinolates trigger a contrasting transcriptomic response in a generalist and a specialist herbivore Insect Biochemistry and Molecular Biology 85:21-31 doi:10.1016/j.ibmb.2017.04.004

Soler R, Bezemer TM, Van Der Putten WH, Vet LEM, Harvey JA (2005) Root herbivore effects on above-ground herbivore, parasitoid and hyperparasitoid performance via changes in plant quality Journal of Animal Ecology 74:1121-1130 doi:10.1111/j.1365-2656.2005.01006.x

Staley JT, Mortimer SR, Morecroft MD, Brown VK, Masters GJ (2007) Summer drought alters plantmediated competition between foliar- and root-feeding insects Global Change Biology 13:866-877 doi:10.1111/j.1365-2486.2007.01338.x

Stevens MT, Lindroth RL (2005) Induced resistance in the indeterminate growth of aspen (Populus tremuloides) Oecologia 145:297-305

Strauss SY, Rudgers JA, Lau JA, Irwin RE (2002) Direct and ecological costs of resistance to herbivory Trends in Ecology \& Evolution 17:278-285 doi:10.1016/S0169-5347(02)02483-7

Thaler JS, Fidantsef AL, Duffey SS, Bostock RM (1999) Trade-offs in plant defense against pathogens and herbivores: A field demonstration of chemical elicitors of induced resistance Journal of Chemical Ecology 25:1597-1609 doi:10.1023/a:1020840900595

Thaler JS, Karban R (1997) A phylogenetic reconstruction of constitutive and induced resistance in Gossypium The American naturalist 149:1139-1146 doi:10.1086/286042

Traw MB (2002) Is induction response negatively correlated with constitutive resistance in black mustard? Evolution 56:2196-2205

Underwood N, Morris W, Gross K, Lockwood III JR (2000) Induced resistance to Mexican bean beetles in soybean: variation among genotypes and lack of correlation with constitutive resistance Oecologia 122:83-89

van Dam NM, Oomen M (2008) Root and shoot jasmonic acid applications differentially affect leaf chemistry and herbivore growth Plant Signaling \& Behavior 3:91-98

van Dam NM, Raaijmakers CE (2005) Local and systemic induced responses to cabbage root fly larvae (Delia radicum) in Brassica nigra and B. oleracea Chemoecology 16:17-24 doi:10.1007/s00049-005-0323-7

van Dam NM, Raaijmakers CE, Van Der Putten WH (2005) Root herbivory reduces growth and survival of the shoot feeding specialist Pieris rapae on Brassica nigra Entomologia Experimentalis et Applicata 115:161-170 doi:10.1111/j.1570-7458.2005.00241.x

van Dam NM, Witjes L, Svatoš A (2004) Interactions between aboveground and belowground induction of glucosinolates in two wild Brassica species New Phytologist 161:801-810 doi:10.1111/j.1469-8137.2004.00984.x

van Geem M, Gols R, van Dam N, van der Putten W, Fortuna T, Harvey J (2013) The importance of aboveground-belowground interactions on the evolution and maintenance of variation in plant defense traits Frontiers in Plant Science 4 doi:10.3389/fpls.2013.00431 
Vandegehuchte ML, de la Peña E, Bonte D (2011) Contrasting covariation of above- and belowground invertebrate species across plant genotypes Journal of Animal Ecology 80:148-158 doi:doi:10.1111/j.1365-2656.2010.01766.x

Vijendravarma RK, Narasimha S, Chakrabarti S, Babin A, Kolly S, Lemaitre B, Kawecki TJ (2015) Gut physiology mediates a trade-off between adaptation to malnutrition and susceptibility to food-borne pathogens Ecology Letters 18:1078-1086 doi:doi:10.1111/ele.12490

Wagner MR, Mitchell-Olds T (2018) Plasticity of plant defense and its evolutionary implications in wild populations of Boechera stricta Evolution 72:1034-1049 doi:10.1111/evo.13469

Zangerl AR, Bazzaz FA (1992) Theory and pattern in plant defense allocation Plant resistance to herbivores and pathogens:363-391

Zangerl AR, Rutledge CE (1996) The probability of attack and patterns of constitutive and induced defense: a test of optimal defense theory The American Naturalist 147:599-608

Züst T, Rasmann S, Agrawal AA (2015) Growth-defense tradeoffs for two major anti-herbivore traits of the common milkweed Asclepias syriaca Oikos 124:1404-1415 doi:10.1111/oik.02075 
642

\section{Tables}

Table 1. Mixed effect model table for testing the effect of JA induction treatment in the roots of Cardamine hirsuta plants, maternal families, and their biomass on individual and total glucosinolates (GSL*), as well as seed production and Spodoptera littoralis larval growth. C. hirsuta plant families nested within populations was the random factor. Family effect was calculated from the log-likelihood difference (LLR) between the full model and the model missing the random effect. 16 GSL out of 28 showed a significant Family effect. GSL 9, 12, 14, 17, 26 showed significant JA effect. GSL 11, 24, 25,26 showed significant biomass effect

\begin{tabular}{|c|c|c|c|c|c|c|}
\hline GSL $\uparrow$ & Factor & Value & Df & t-value/LLR & p-value & \\
\hline \multirow[t]{3}{*}{ GSL1 } & JA & 0.11 & 91 & 1.154 & 0.252 & \\
\hline & Plant biomass & 0 & 91 & -0.896 & 0.373 & \\
\hline & Family & & 4 & 1.735 & 0.187 & \\
\hline \multirow[t]{3}{*}{ GSL2 } & JA & -0.062 & 91 & -1.19 & 0.237 & \\
\hline & Plant biomass & 0 & 91 & 0.055 & 0.956 & \\
\hline & Family & & 4 & 0 & 1 & \\
\hline \multirow[t]{3}{*}{ GSL3 } & JA & 0.063 & 91 & 0.88 & 0.381 & \\
\hline & Plant biomass & 0 & 91 & 0.769 & 0.444 & \\
\hline & Family & & 4 & 12.671 & 0 & $* * *$ \\
\hline \multirow[t]{3}{*}{ GSL4 } & JA & 0.047 & 91 & 0.433 & 0.666 & \\
\hline & Plant biomass & 0 & 91 & 1.362 & 0.177 & \\
\hline & Family & & 4 & 51.395 & 0 & $* * *$ \\
\hline \multirow[t]{3}{*}{ GSL5 } & JA & 0.036 & 91 & 0.394 & 0.695 & \\
\hline & Plant biomass & 0 & 91 & 0.673 & 0.502 & \\
\hline & Family & & 4 & 6.591 & 0.01 & $* *$ \\
\hline \multirow{3}{*}{ GSL6 } & JA & 0.025 & 91 & 0.15 & 0.881 & \\
\hline & Plant biomass & 0 & 91 & -0.104 & 0.918 & \\
\hline & Family & & 4 & 0.099 & 0.753 & \\
\hline \multirow{3}{*}{ GSL7 } & JA & 0 & 91 & -0.005 & 0.996 & \\
\hline & Plant biomass & 0 & 91 & 0.118 & 0.907 & \\
\hline & Family & & 4 & 7.301 & 0.006 & $* *$ \\
\hline \multirow{3}{*}{ GSL8 } & JA & 0.047 & 91 & 0.284 & 0.777 & \\
\hline & Plant biomass & 0.001 & 91 & 1.491 & 0.139 & \\
\hline & Family & & 4 & 18.37 & 0 & $* * *$ \\
\hline \multirow[t]{3}{*}{ GSL9 } & JA & -0.086 & 91 & -2.846 & 0.006 & $* *$ \\
\hline & Plant biomass & 0 & 91 & -0.299 & 0.766 & \\
\hline & Family & & 4 & 27.569 & 0 & $* * *$ \\
\hline \multirow[t]{3}{*}{ GSL10 } & JA & -0.02 & 91 & -0.297 & 0.768 & \\
\hline & Plant biomass & 0 & 91 & 0.33 & 0.742 & \\
\hline & Family & & 4 & 3.254 & 0.071 & $\circ$ \\
\hline \multirow[t]{3}{*}{ GSL11 } & JA & 0.094 & 91 & 1.178 & 0.242 & \\
\hline & Plant biomass & 0 & 91 & 2.168 & 0.033 & $* *$ \\
\hline & Family & & 4 & 19.56 & 0 & $* * *$ \\
\hline \multirow[t]{3}{*}{ GSL12 } & JA & -0.095 & 91 & -1.769 & 0.08 & $\circ$ \\
\hline & Plant biomass & 0 & 91 & 0.808 & 0.421 & \\
\hline & Family & & 4 & 3.021 & 0.082 & $\circ$ \\
\hline
\end{tabular}




\begin{tabular}{|c|c|c|c|c|c|c|}
\hline GSL13 & JA & 0.036 & 91 & 0.605 & 0.547 & \\
\hline & Plant biomass & 0 & 91 & 1.476 & 0.143 & \\
\hline & Family & & 4 & 21.435 & 0 & $* * *$ \\
\hline \multirow[t]{3}{*}{ GSL14 } & JA & -0.112 & 91 & -2.165 & 0.033 & $* *$ \\
\hline & Plant biomass & 0 & 91 & 0.046 & 0.963 & \\
\hline & Family & & 4 & 3.043 & 0.081 & $\circ$ \\
\hline \multirow[t]{3}{*}{ GSL15 } & JA & -0.081 & 91 & -1.019 & 0.311 & \\
\hline & Plant biomass & 0 & 91 & -0.517 & 0.606 & \\
\hline & Family & & 4 & 0.031 & 0.859 & \\
\hline \multirow[t]{3}{*}{ GSL16 } & JA & 0.062 & 91 & 0.884 & 0.379 & \\
\hline & Plant biomass & 0 & 91 & 0.172 & 0.864 & \\
\hline & Family & & 4 & 1.783 & 0.181 & \\
\hline \multirow{3}{*}{ GSL17 } & JA & -0.094 & 91 & -1.74 & 0.085 & $\circ$ \\
\hline & Plant biomass & 0 & 91 & 0.754 & 0.453 & \\
\hline & Family & & 4 & 2.751 & 0.097 & \\
\hline \multirow{3}{*}{ GSL18 } & JA & 0.021 & 91 & 0.126 & 0.9 & \\
\hline & Plant biomass & 0 & 91 & 0.44 & 0.661 & \\
\hline & Family & & 4 & 0 & 1 & \\
\hline \multirow{3}{*}{ GSL19 } & JA & -0.092 & 91 & -1.71 & 0.091 & \\
\hline & Plant biomass & 0 & 91 & 0.778 & 0.439 & \\
\hline & Family & & 4 & 2.579 & 0.108 & \\
\hline \multirow[t]{3}{*}{ GSL20 } & JA & -0.057 & 91 & -1.535 & 0.128 & \\
\hline & Plant biomass & 0 & 91 & -0.393 & 0.696 & \\
\hline & Family & & 4 & 0.857 & 0.005 & $* *$ \\
\hline \multirow[t]{3}{*}{ GSL21 } & JA & -0.091 & 91 & -1.768 & 0.081 & \\
\hline & Plant biomass & 0 & 91 & -0.052 & 0.959 & \\
\hline & Family & & 4 & 2.735 & 0.098 & $\circ$ \\
\hline \multirow{3}{*}{ GSL22 } & JA & 0.113 & 91 & 0.804 & 0.424 & \\
\hline & Plant biomass & 0 & 91 & -0.228 & 0.821 & \\
\hline & Family & & 4 & 14.837 & 0 & $* * *$ \\
\hline \multirow[t]{3}{*}{ GSL23 } & JA & -0.091 & 91 & -1.768 & 0.081 & $\circ$ \\
\hline & Plant biomass & 0 & 91 & -0.052 & 0.959 & \\
\hline & Family & & 4 & 2.735 & 0.098 & o \\
\hline \multirow[t]{3}{*}{ GSL24 } & JA & 0.069 & 91 & 0.634 & 0.528 & \\
\hline & Plant biomass & -0.001 & 91 & -4.379 & 0 & $* * *$ \\
\hline & Family & & 4 & 0.812 & 0.367 & \\
\hline \multirow[t]{3}{*}{ GSL25 } & JA & -0.009 & 91 & -0.081 & 0.935 & \\
\hline & Plant biomass & -0.002 & 91 & -5.913 & 0 & $* * *$ \\
\hline & Family & & 4 & 3.536 & 0.06 & $\circ$ \\
\hline \multirow[t]{3}{*}{ GSL26 } & JA & 0.04 & 91 & 1.888 & 0.062 & $\circ$ \\
\hline & Plant biomass & 0 & 91 & -3.367 & 0.001 & $* *$ \\
\hline & Family & & 4 & 9.61 & 0.002 & $* * *$ \\
\hline \multirow[t]{3}{*}{ GSL27 } & JA & -0.089 & 91 & -1.649 & 0.103 & \\
\hline & Plant biomass & 0 & 91 & 0.199 & 0.843 & \\
\hline & Family & & 4 & 1.311 & 0.252 & \\
\hline
\end{tabular}


bioRxiv preprint doi: https://doi.org/10.1101/810432; this version posted October $18,2019$. The copyright holder for this preprint (which was not certified by peer review) is the author/funder, who has granted bioRxiv a license to display the preprint in perpetuity. It is made available under aCC-BY-NC-ND 4.0 International license.

643

644

645

646

647

648

649

650

651

652

653

\begin{tabular}{|l|l|l|l|l|l|l|}
\hline GSL28 & JA & -0.109 & 91 & -2.082 & 0.04 & \\
\hline & Plant biomass & 0 & 91 & -0.027 & 0.978 & \\
\hline & Family & & 4 & 1.966 & 0.161 & \\
\hline GSL Total & JA & 0.029 & 91 & 0.194 & 0.847 & \\
\hline & Plant biomass & 0 & 91 & 0.489 & 0.626 & \\
\hline & Family & & 4 & 0 & 1 & \\
\hline Seed production & JA & -80.991 & 116 & -1.697 & 0.092 & $\circ$ \\
\hline & Plant biomass & 0.171 & 116 & 1.206 & 0.23 & \\
\hline & Family & & 4 & 19.551 & 0 & $* * *$ \\
\hline S. littoralis & JA & -0.835 & 92 & -4.736505 & 0 & $* * *$ \\
\hline & Plant biomass & 0 & 92 & -0.087 & 0.93 & \\
\hline & Family & & 4 & 13.989 & 0 & $* * *$ \\
\hline P. brassicae & JA & & 92 & & 0.2 & \\
\hline & Plant biomass & & 92 & & 0.4 & \\
\hline & Family & & 4 & & 0.32 & \\
\hline
\end{tabular}

Signif. codes: $\quad * * *<0.001,{ }^{* *}<0.01, *<0.05,{ }^{\circ}<0.1$

$\uparrow$ GSL1 = Glucoraphanin; GSL2 = Hydroxypropyl gs1; GSL3 = Progoitrin; GSL4 = Glucoalyssin; GSL5 = Glucoputranjivin; GSL6 = Gluconapin; GSL7 = Butyl gsl; GSL8 = Glucobrassicanapin; GSL9 = Glucohirsutin; GSL10 = Glucoerucin; GSL11 = Glucoberteroin; GSL12 = 8-Methylthiooctyl gsl ; GSL13 = Gluconapoleiferin; GSL14 = Hydroxymethylbutyl gsl ; GSL15 = 2-Methylbutyl gsl; GSL16 = Sinalbin; GSL17 = Veratryl gsl; GSL18 = Glucotropeolin; GSL19 = Trimethoxy gs1; GSL20 = 5-Benzoyloxypentyl ; GSL21 = 2-Hydroxy-2-phenylethyl gsl; GSL22 = Gluconasturtiin; GSL23 = Hydroxybenzyl-methylether gsl; GSL24 = Glucobrassicin; GSL25 = Methoxyglucobrassicin; GSL26 $=$ Neoglucobrassicin; GSL27 = Unknown.C16H23NO10S2; GSL28 = Unknown.C19H28N3O12S3. 
Table 2. Permutational multivariate analysis of variance (PERMANOVA) table for testing the effect

655 of JA treatment and family on the structure of the glucosinolate (GSLs) matrix.

656

\begin{tabular}{|l|l|l|l|l|l|}
\hline Factor & Df & MSQ & F value & $\mathrm{R}^{2}$ & P value \\
\hline JA treatment & 1 & 0.136213 & 2.04795 & 0.01494 & 0.118 \\
\hline Family & 25 & 0.126121 & 1.89621 & 0.34592 & $\mathbf{0 . 0 0 5 * *}$ \\
\hline Plant biomass & 1 & 0.192319 & 2.89149 & 0.0211 & $\mathbf{0 . 0 5 4}$ \\
\hline JA * Family & 25 & 0.063047 & 0.94791 & 0.17292 & 0.571 \\
\hline Residuals & 61 & 0.066512 & & 0.44512 & \\
\hline
\end{tabular}

657

658

659

660

661 


\section{Figure legends}

663

664

665

666

667

668

669

670

671

672

673

674

675

676

677

678

679

680

681

682

683

684

685

686

687

688

689

690

691

692

Fig. 1. Root to shoot induction of resistance against generalist and specialist herbivores. Boxplots show average weight gain of (a) Spodoptera littoralis, and (b) Pieris brassicae caterpillars feeding on plants that received jasmonic acid (JA) in the roots 4 days prior herbivory (JA, grey boxes), or received no $\mathrm{JA}$ in the roots (Control, open boxes)). Weight gain was calculated as the natural logarithm of the difference between final and initial fresh weight. Asterisks show significant differences across the two treatments $(\mathrm{p}<0.05)$.

Fig. 2. Genetic variation in resistance and fitness related traits. Shown are reaction norm plots for the effects of JA treatment in roots on a) the weight gain of $S$. littoralis caterpillars, and b) total seed production across 26 maternal half-sib families of $C$. hirsuta plants subjected to herbivory by $S$. littoralis. Grey lines represent maternal families' averages in the constitutive (Control) state and in the induced state after JA addition the roots (JA). Black lines and dots represent overall averages across families.

Fig. 3. Glucosinolate (GSL) production across Cardamine hirsuta half-sib families. a) Barplot representation of the concentration of the individual GSLs in leaves of $C$. hirsuta plants that either received JA in the roots 4 days prior to the start of herbivory (JA, grey bars), or did not receive JA treatment in the roots (Control, open bars). Asterisks indicate a significant effect of JA treatment in production of GSLs. GSL1 = Glucoraphanin; GSL2 = Hydroxypropyl gs1; GSL3 = Progoitrin; GSL4 = Glucoalyssin; GSL5 = Glucoputranjivin; GSL6 = Gluconapin; GSL7 = Butyl gsl; GSL8 = Glucobrassicanapin; GSL9 = Glucohirsutin; GSL10 = Glucoerucin; GSL11 = Glucoberteroin; GSL12 = 8-Methylthiooctyl gs1 ; GSL13 = Gluconapoleiferin; GSL14 = Hydroxymethylbutyl gs1 ; GSL15 = 2-Methylbutyl gsl; GSL16 = Sinalbin; GSL17 = Veratryl gsl; GSL18 = Glucotropeolin; GSL19 = Trimethoxy gsl; GSL20 = 5-Benzoyloxypentyl ; GSL21 = 2-Hydroxy-2-phenylethyl gs1; GSL22 = Gluconasturtiin; GSL23 = Hydroxybenzyl-methylether gsl; GSL24 = Glucobrassicin; GSL25 = Methoxyglucobrassicin; GSL26 = Neoglucobrassicin; GSL27 = Unknown.C16H23NO10S2; GSL28 = Unknown.C19H28N3O12S. b) Non-multidimensional scaling (nMDS) ordination of the individual glucosinolates found in C. hirsuta leaves across 26 plant families at the constitutive state (open dots), or after roots induction with JA (black dots). Numbers besides dots correspond to plant families. 
694

695

696

697

698

699

700

701

702

703

704

705

706

707

708

709

710

711

712

713

714

715

716

717

718

719

720

721

722

723

724

Fig. 4. Herbivore impact on plant fitness. Boxplots show the total seed number produced by 26 maternal half-sib families of $C$. hirsuta plants in plants that did not receive JA in the roots nor treated aboveground herbivory (No herbivory), plants that received jasmonic acid (JA) in the roots 4 days prior to the start of herbivory by Spodoptera littoralis or Pieris brassicae (P. brassicae / JA, S. littoralis / JA), and plants subjected to herbivory either by $S$. littoralis or P. brassicae but that that were not treated by JA in the roots (P. brassicae / C, S. littoralis / C).

Fig. 5. Fitness benefits of JA root induction during herbivory. Shown are interaction plots indicating the relationship between the total seed production and total glucosinolates, as well as seven individual GSLs that showed interaction with JA across all plants subjected to herbivory by $S$. littoralis in control and JA treatment (see Table S3). 
bioRxiv preprint doi: https://doi.org/10 1101/810432; this version posted October 18, 2019. The copyright holder for this preprint (which was not certified by peer review) is the author/funder, who has granted bioRxiv a license to display the preprint in perpetuity. It is made available under aCC-BY-NC-ND 4.0 International license.

Figures

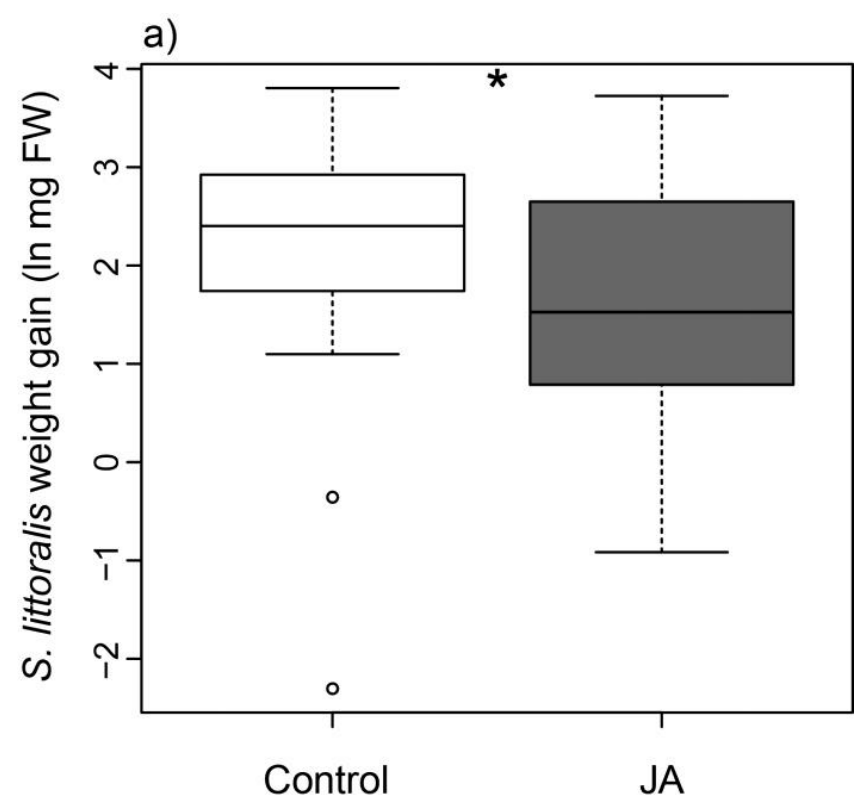

b)

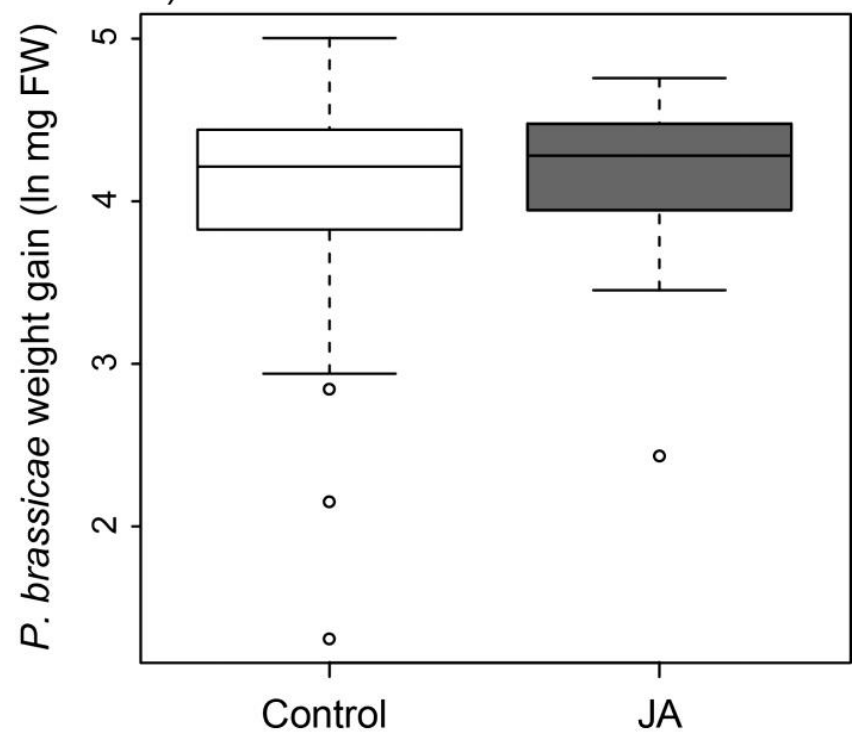

Fig. 1 
a)

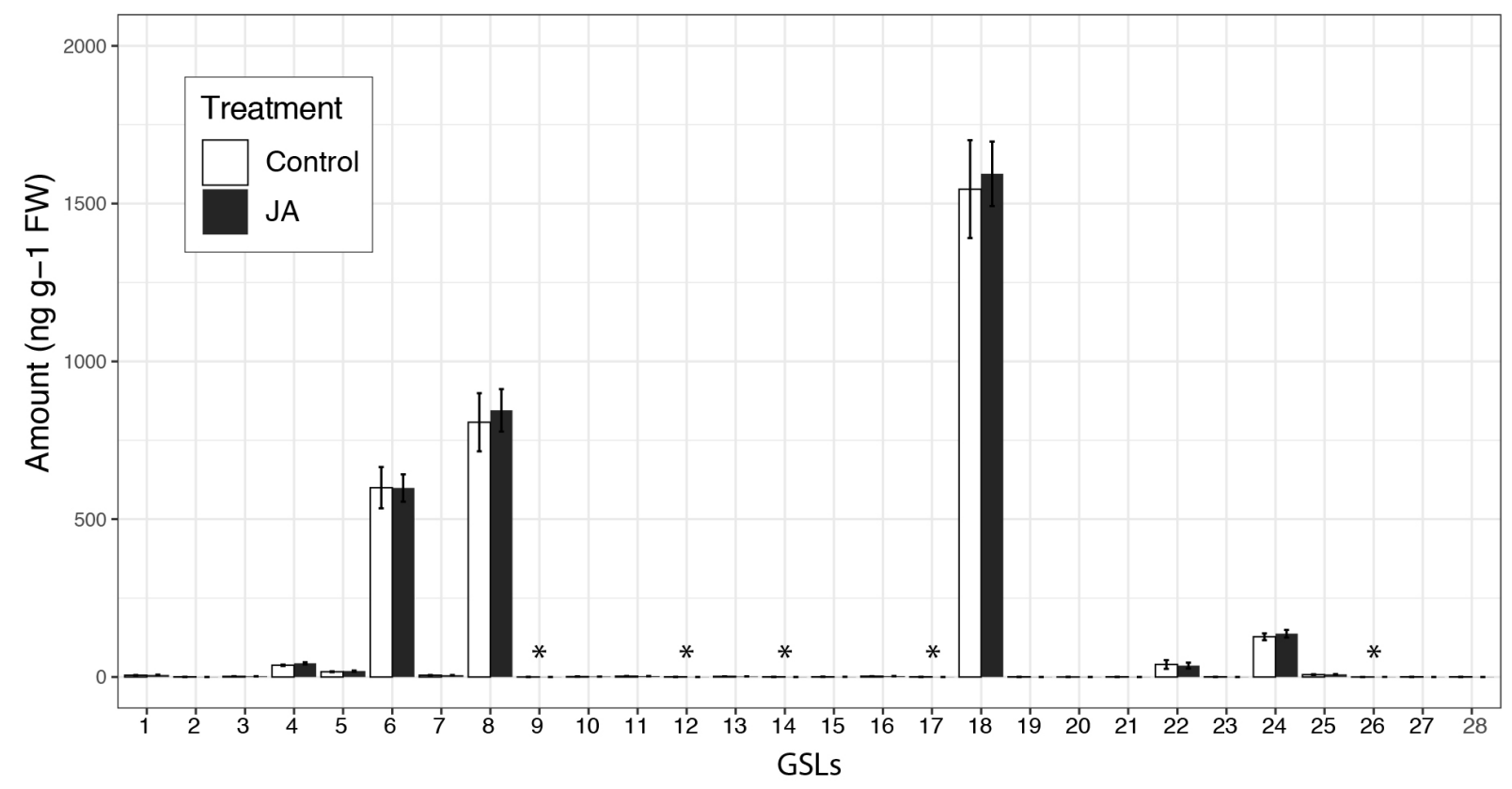

b)

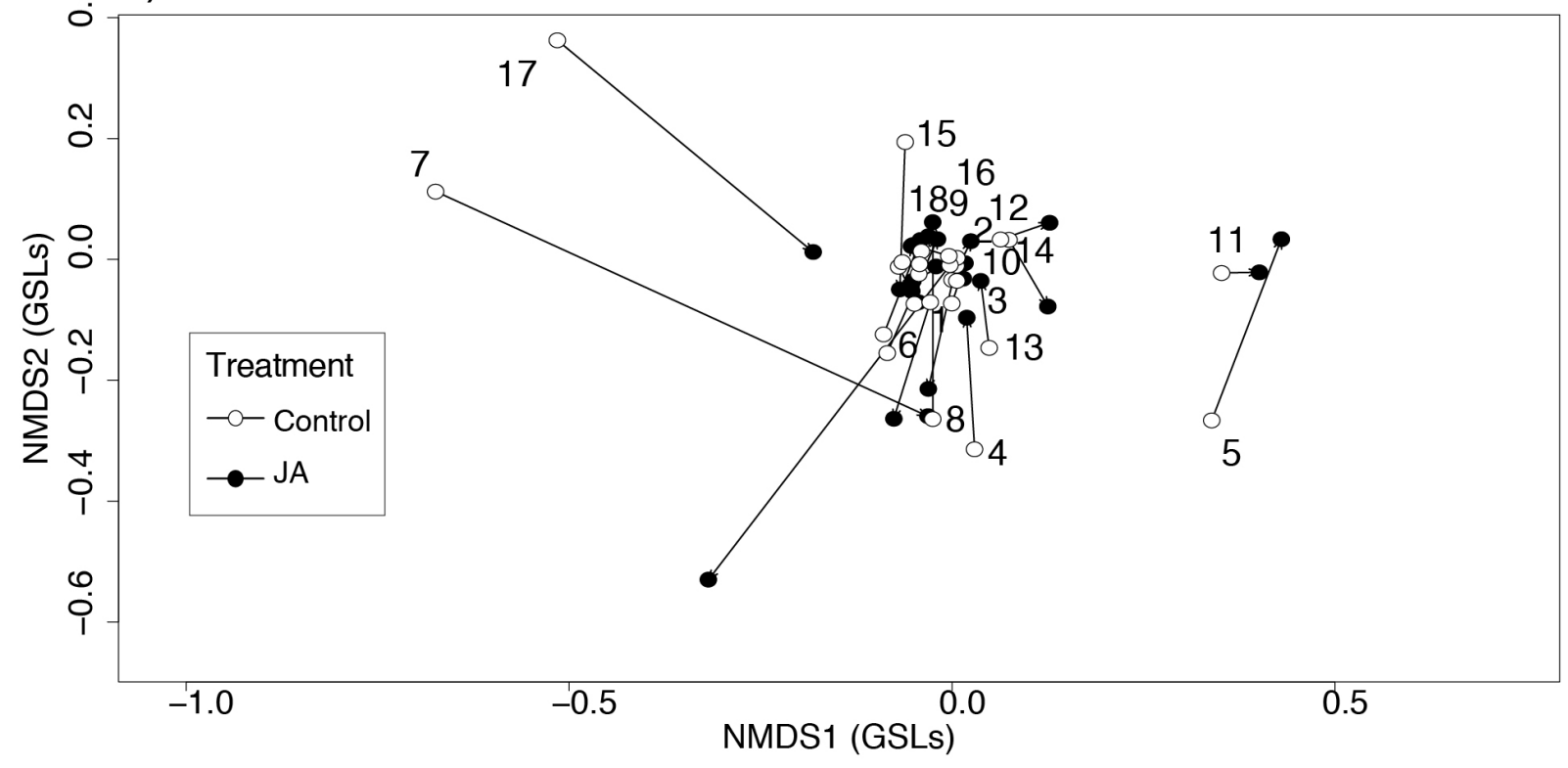

Fig. 2 
a)

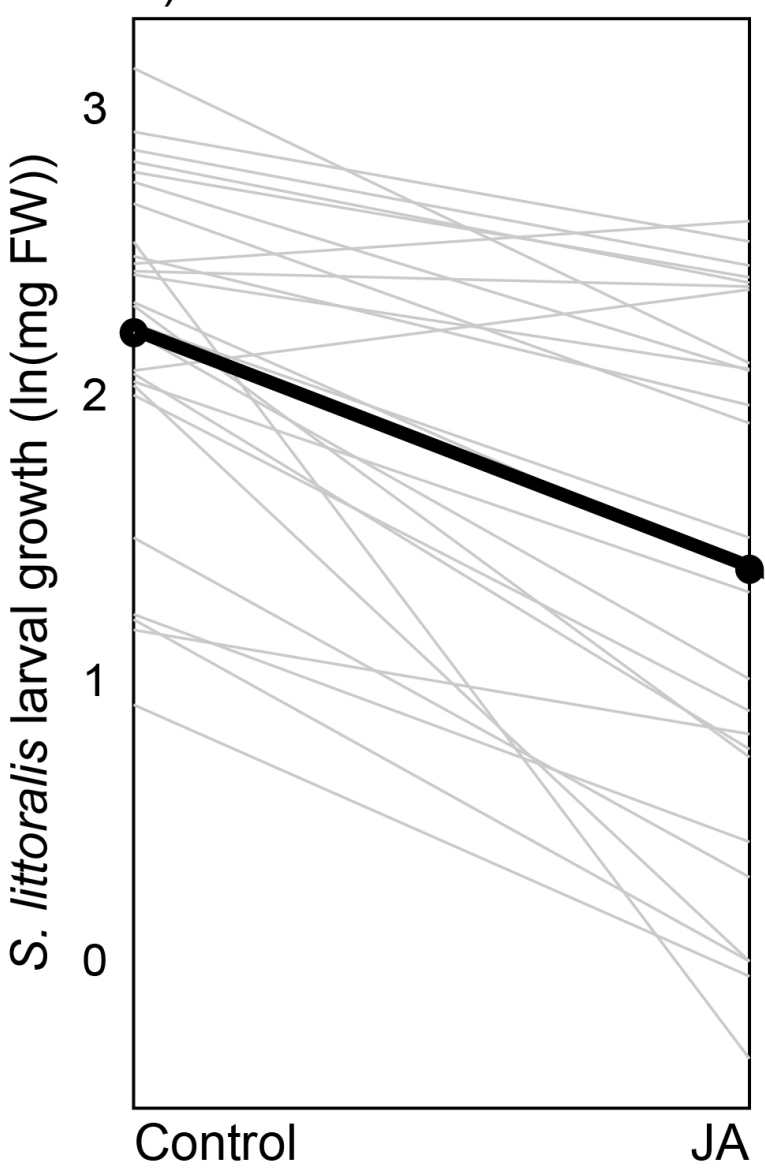

b)

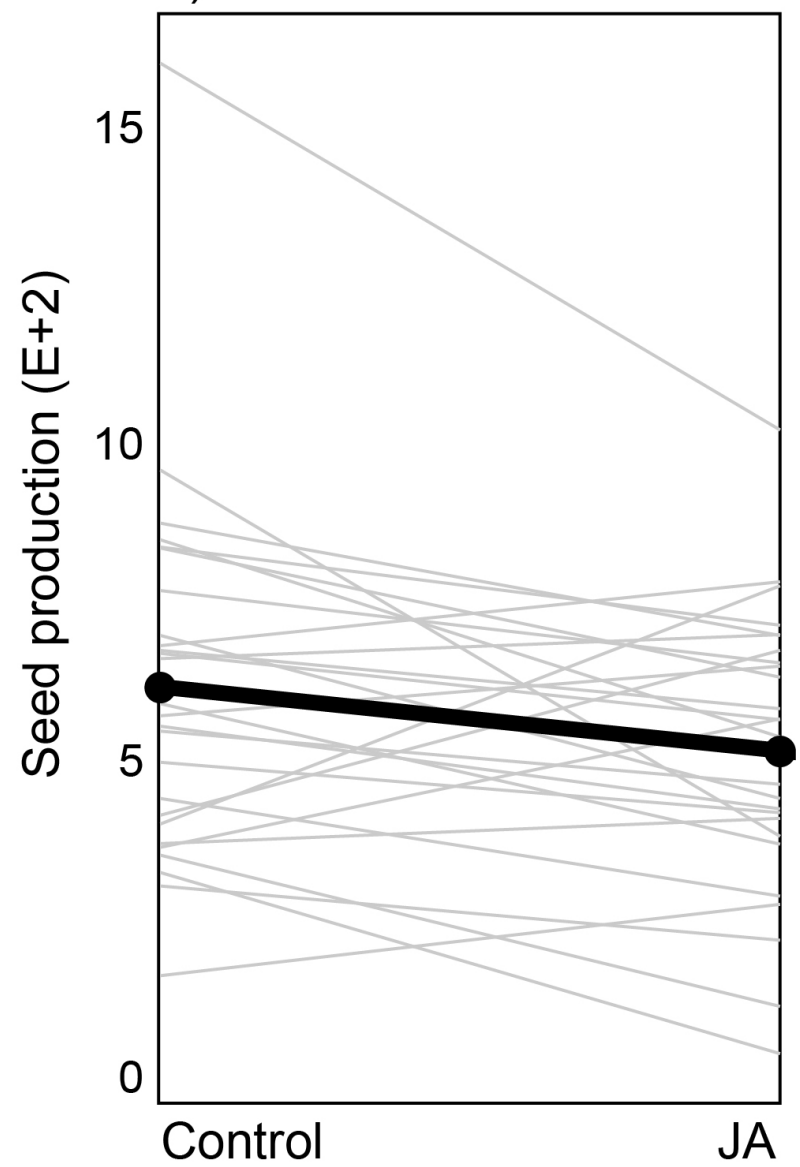

Fig. 3 
bioRxiv preprint doi: https://doi.org/10.1101/810432; this version posted October 18, 2019. The copyright holder for this preprint (which was not certified by peer review) is the author/funder, who has granted bioRxiv a license to display the preprint in perpetuity. It is made available under aCC-BY-NC-ND 4.0 International license.

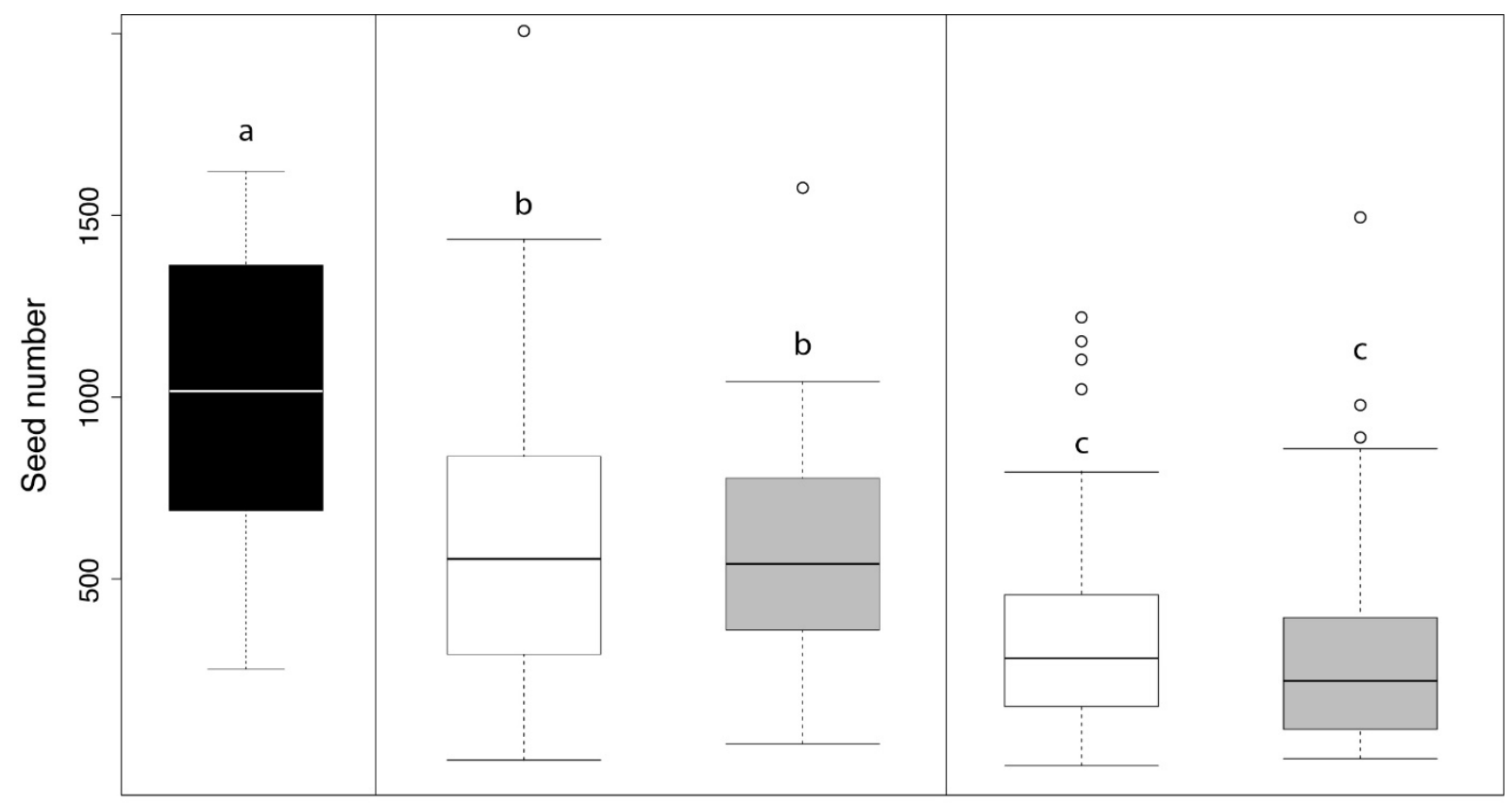

S. littoralis / C

S. littoralis / JA

P. brassicae / C

P. brassicae / JA

Fig. 4 
bioRxiv preprint doi: https://doi.org/10 1101/810432; this version posted October 18,2019 . The copyright holder for this preprint (which was not certified by peer review) is the author/funder, who has granted bioRxiv a license to display the preprint in perpetuity. It is made available under aCC-BY-NC-ND 4.0 International license.

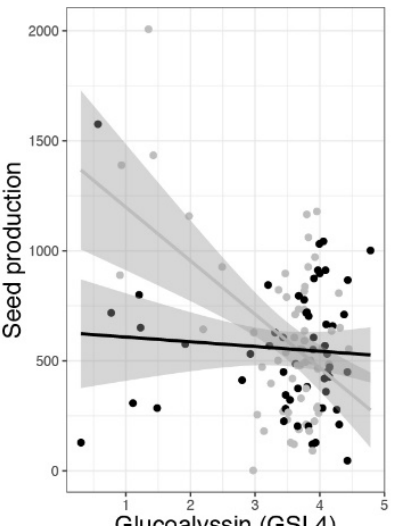

Glucoalyssin (GSL4)

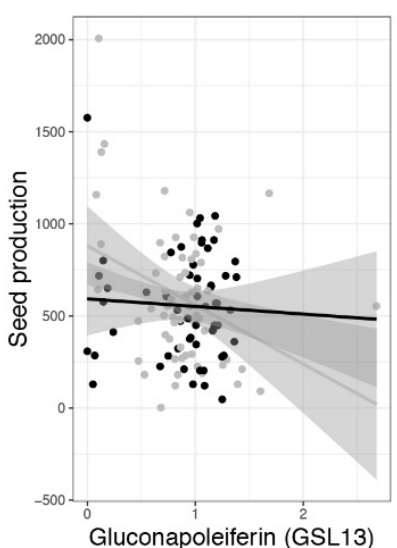

Gluconapoleiferin (GSL13)
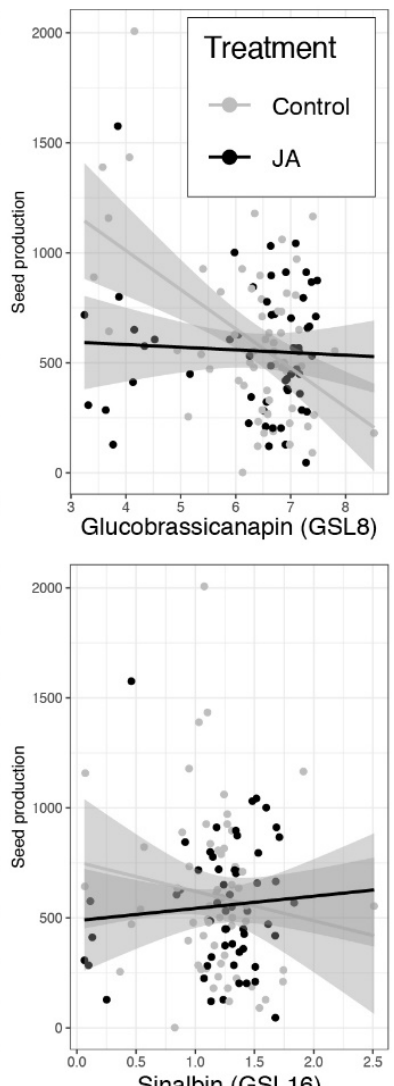

Sinalbin (GSL16)
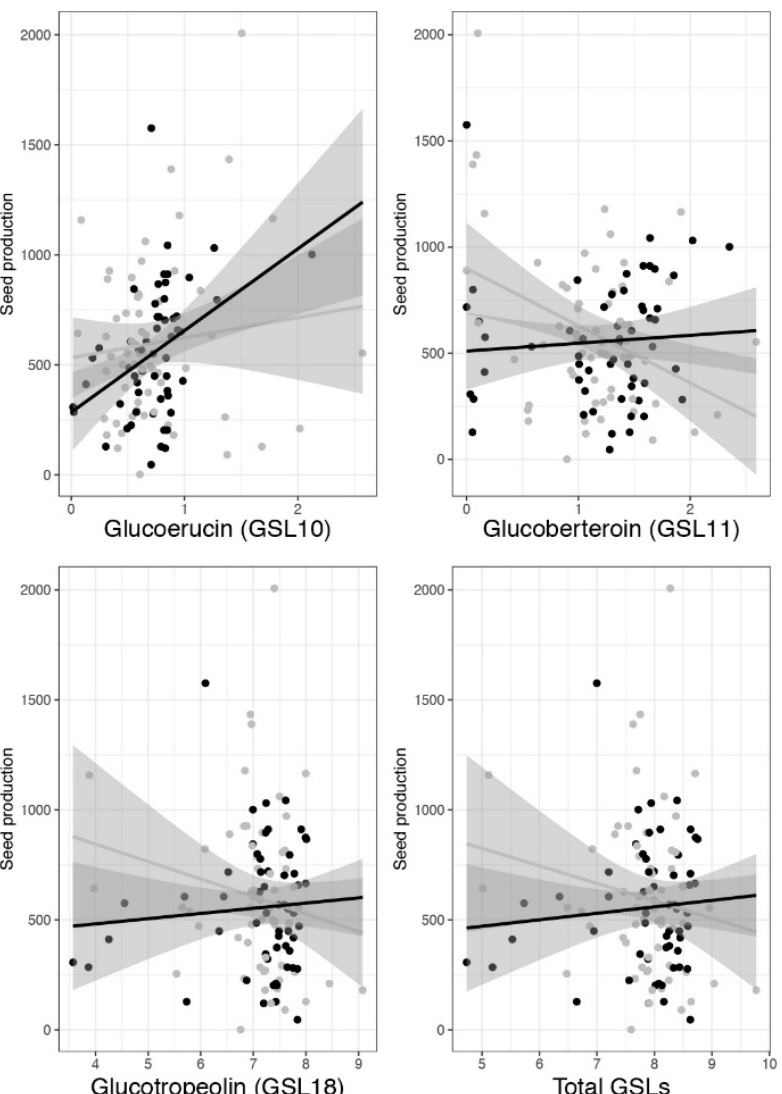

Fig. 5 